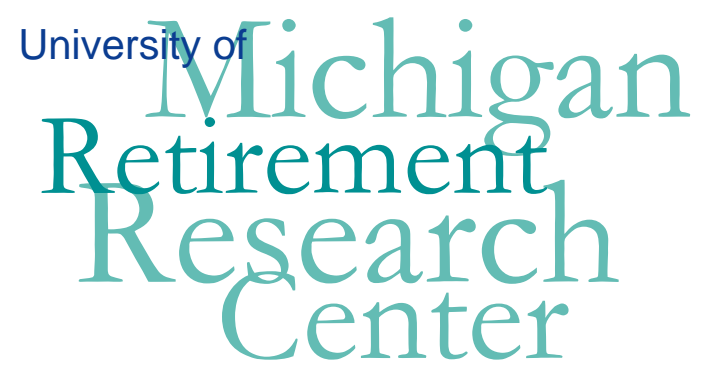

Working Paper

WP 2009-209

\title{
Investor Behavior and Fund Performance under a Privatized Retirement Accounts System: Evidence from Chile
}

Elena Krasnokutskaya and Petra Todd

\begin{tabular}{|l|l|l|l|l|l|}
\hline $\mathrm{M}$ & $\mathrm{R}$ & Project \#: UM09-17 \\
\hline $\mathrm{R}$ & $\mathrm{C}$ &
\end{tabular} 



\title{
Investor Behavior and Fund Performance under a Privatized Retirement Accounts System: Evidence from Chile
}

\author{
Elena Krasnokutskaya \\ University of Pennsylvania \\ Petra Todd \\ University of Pennsylvania
}

September 2009

\author{
Michigan Retirement Research Center \\ University of Michigan \\ P.O. Box 1248 \\ Ann Arbor, MI 48104 \\ http://www.mrrc.isr.umich.edu/ \\ (734) 615-0422
}

\section{Acknowledgements}

This work was supported by a grant from the Social Security Administration through the Michigan Retirement Research Center (Grant \# 10-M-98362-5-01). The findings and conclusions expressed are solely those of the author and do not represent the views of the Social Security Administration, any agency of the Federal government, or the Michigan Retirement Research Center.

\section{Regents of the University of Michigan}

Julia Donovan Darrow, Ann Arbor; Laurence B. Deitch, Bingham Farms; Denise Ilitch, Bingham Farms; Olivia P. Maynard, Goodrich; Andrea Fischer Newman, Ann Arbor; Andrew C. Richner, Grosse Pointe Park; S. Martin Taylor, Gross Pointe Farms; Katherine E. White, Ann Arbor; Mary Sue Coleman, ex officio 


\title{
Investor Behavior and Fund Performance under a Privatized Retirement Accounts System: Evidence from Chile
}

\begin{abstract}
In the U.S. and in Chile, there have been heated debates about the relative merits of a decentralized privatized pension system relative to a more traditional social security system. On the firm side, there are concerns that pension funds engage in anticompetitive behavior and take advantage of consumers' by charging high fees and account maintenance changes. On the consumer side, there are concerns that consumers do not select wisely among funds and take on too much risk. Any pension system with insurance features to protect against low levels of pension accumulations is potentially subject to moral hazard problems, in the form of consumers' taking on too much risk. In the case of Chile, the government provides a minimum pension benefit to those with low pension accumulations, which can make some consumers more willing to take risks. For these reasons, the Chilean government introduced regulations on pension fund firms' investments designed to limit risk. This paper analyzes the determinants of consumers' choices of pension fund and of pension fund characteristics (performance and fees), taking into account governmental regulations. In particular, it estimates a demand and supply model of the pension fund investment market using a longitudinal household dataset gathered in 2002 and 2004 in Chile, administrative data on fund choices, and longitudinal data on cost determinants of pension funds. We find that the existing regulation actually increases the level of risk in the market, reduces heterogeneity across firms, and reduces incentives for consumers to participate in the pension fund program. We suggest alternative more effective forms of regulation.
\end{abstract}

\section{Authors’ Acknowledgements}

We thank David Bravo, Jere Behrman, Ludwig Ressner, and Olivia Mitchell for helpful discussions. This paper benefited from comments received at the Yale Cowles Foundation 2009 summer conference. We are also grateful to Jose Ruiz and Viviana Velez-Grajales for help in collecting the pension fund cost and return data series and in understanding pension fund fees and regulations. Solange Bernstein of the AFP regulatory agency provided helpful assistance in understanding the structure and coding of the administrative dataset and Javiera Vasquez Nunez was very helpful in the preparation of the datasets. We also thank Chao Fu, Clement Joubert, Edith Liu and Naoki Wakamori for able research assistance at various points over the couse of this project. The authors gratefully acknowledge financial support from a Michigan Retirement Research Center grant (\#UM-0917), and, in the early stages of this research, from a pilot grant funded by the National Institutes of Health-National Institute on Aging, Grant No. P30 AG012836 (B.J. Soldo, PI), the National Institutes of Health-National Institute of Child Health and Human Development, Grant No. R24 HD-044964 (H.L. Smith, PI), and the Boettner Center for Pensions and Retirement Security at the University of Pennsylvania (O.S. Mitchell, Director). The collection of the EPS dataset used in this project was funded in part by NIH R01-543250 (P.E. Todd, PI). 


\section{Introduction}

The United States and many European countries are currently considering how best to reform their pay-as-you-go social security systems. Demographic trends indicate rising numbers of pensioners per worker and pending insolvency of many social security systems. The kinds of reforms being considered include increasing the required social security contribution per worker, raising the standard retirement age, or overhauling the system by transiting to a fully funded system. Chile has been at the forefront of pension reforms, having switched to a fully funded private retirement accounts system twenty eight years ago. ${ }^{1}$ Numerous other Latin American countries followed suit, building on the Chilean model. These include (with years of adoption in parentheses) Peru (1993), Colombia (1994), Argentina (1994), Uruguay (1996), Bolivia (1997), Mexico (1997), El Salvador (1998), Costa Rica (2001), the Dominican Republic (2003), Nicaragua (2004) and Equador (2004). ${ }^{2}$

Previous research on Chile mainly examined the impact of pension reforms on the macro-economy, capital markets and aggregate savings. ${ }^{3}$ It found substantial benefits of moving to a private retirement accounts system in developing well-functioning capital markets and stimulating economic growth. However, there continues to be a heated debate about other relative merits of a decentralized, private system. Critics of privatization point to low coverage rates and commissions and fees that are thought to be excessive. ${ }^{4}$ Low coverage rates are mainly due to the presence of an informal sector of the economy, where workers do not contribute to the system, and to low labor force participation among some groups in the population, such as women. ${ }^{5}$ With

\footnotetext{
${ }^{1}$ University of Chicago economists played a role in the early adoption of the privatized account system under Pinochet's military regime.

${ }^{2}$ Cogan and Mitchell (2003) discuss prospects for funded individual defined contributions acount pensions in the United States.

${ }^{3}$ Many have written on Chilean pensions system (e.g. Cheyre, 1988; Iglesias and Acuña, 1991; Baeza, Margozzini, Arroyo, 1995, and SAFP, 1998). Some of the literature is summarized in Arenas de Mesa, Bravo, Behrman, Mitchell, and Todd (2006).

${ }^{4}$ A recent critique citing the problem of low coverage rates is Holzmann, Hinz et. al. (2005).

${ }^{5}$ See Arenas de Mesa, Bravo, Behrman, Mitchell, and Todd (2006).
} 
regard to commissions and fees, it was initially thought that free market entry and competition among fund administrators (called AFPs) would ensure that fees and commissions would be kept at minimal levels. However, low rates of financial literacy may be a factor inhibiting consumers from selecting wisely among plans, which could facilitate the survival of higher cost AFPs. ${ }^{6}$

The proposed plans for pension reform in the US and in Europe have many features in common with Chile's current pension plan. They outline a system under which all workers are mandated to contribute a pre-specified part of their income to their pension account, which is managed by money manager(s) (either a government owned company or competitive industry of money managers). The government serves as a last resort guarantor, supplementing pension income if pension accumulations are insufficient upon retirement (below pre-specified minimal level) either because of low income or unfavorable returns on investment. All these features are present in Chilean pension fund system, called the Administradoras de Fondos de Pensiones (AFPs).

Two important concerns have been raised about fully funded pension systems. The first is that government obligations can be large, particularly in years with unfavorable market returns on investments. Second, the government guarantee of minimal support may induce moral hazard problems by providing incentives for consumers with low income to choose risky investment options. If the system is run by a competitive industry then money managers may offer products to meet this riskier demand, which, in turn, can raise government obligations. This is clearly undesirable feature of a competitive pension fund industry, although competition can also bring benefits of more efficient pricing, incentives for costs efficiency and quality improvement.

\footnotetext{
${ }^{6}$ Regulations in Chile stipulate that the pension fund regulatory agency supply consumers with regular quarterly reports that compare the performance and costs of funds, but only about half of those surveyed in our household survey data report having read their reports. The report is called the "Cartola."
} 
Chile has a competitive industry overseeing pension investment that is subject to government regulations that are designed to promote transparency of fees, to facilitate switching among funds and to limit the riskiness of the investment products offered. A particularly important regulation is a return requirement under which money managers are responsible with their capital for delivering a rate of return no lower than $2 \%$ below industry average. ${ }^{7}$ This regulation essentially shifts some of the risk of investment from consumers to the pension fund firm.

This paper investigates the choice of product and subsequent pricing in the Chilean pension investment industry, that we model as oligopolistic. More specifically, we investigate effectiveness of the Chilean regulation in limiting risk in the system and compare in to alternative forms of regulation. The question of whether and to what extent governmental regulations imposed on a privatized account system can protect investors from risk without too greatly compromising investment returns is pertinent not only for Chile but also for any other country considering a move to a privatized account system.

Our analysis combines data from multiple sources: longitudinal household survey data gathered in 2002 and 2004, administrative data on contributions and fund choices from 1981-2004 that was obtained from the pension fund regulatory agency, market data on the performance of the various funds, and a data series on the fees charged by funds as well as accounting cost data. The household survey data come from the 2002 Historia Laboral y Seguridad Social (HLLS) survey and the 2004 Enquesta Proteccion Sociale (EPS) follow up survey. The data contain demographic and labor market information on 17,246 individuals age 15 or older, including information on household demographics, work history, pension plan participation, and savings, as

\footnotetext{
${ }^{7}$ There is also a regulation that requires AFP firms that have returns in excess of $2 \%$ above the market average to keep the excess in a reserve fund to be used in the event of reaching the lower return bounday. In practice, the upper limit was only reached once by two firms (Fomenta and Valora). In that case, the excess return was paid out to the investors when the firms merged. In this paper, we ignore the upper bound on AFP returns, which essentially assumes that consumers get any excess returns. The upper bound was eliminated in 2008.
} 
well as more limited information on health, assets, disability status and utilization of medical services.

Under the Chilean pension system, consumers are required to invest all their pension accumulations with one money manager. However, they can freely move their savings from one money manager to another. Additionally, the funds are not allowed to charge a fee to set up an account or to withdraw money. We develop a model of consumer choices among AFP funds that assumes that the consumer chooses an AFP to manage his/her pension savings at the beginning of each period (annually). The consumer's choice of investment fund at a given point of time depends on the product's characteristics (mean return and risk) and on the fees charged by that fund. Chilean pension funds charge fixed and variable fees that depend on contribution levels. A fund with a high fixed fee but a low variable fee might be lowest cost for a consumer with a high contribution level, whereas a fund with zero fixed fee but a high variable fee might be lowest cost for someone with a low contribution level. Our modeling framework also allows for observable and unobservable sources of heterogeneity in risk preferences across consumers as well as unobservable attributes of pension fund firms that may, in addition to fund performance, affect perceptions of fund quality. Repeated pension fund choices over time determine the consumer's balance accumulation. Aggregation over consumers generates the market demand for an AFP product. Additionally, we model consumer's decision of whether to contribute or not in a given period as a decision of whether to be employed in a formal or informal sector in a given time period (contribution to the pension system is mandatory for workers in the formal sector).

The supply side of the market is modeled as an oligopolistic environment in which AFPs sequentially choose location (mean return and risk) and fees, taking into account the distribution of consumers' preferences and consumer types as defined by consumer characteristics. We rigorously justify our supply side model and the esti- 
mation procedure in a companion paper, Krasnokutskaya, Ressner and Todd (2008) that also proves existence of equilibrium.

The demand side of the model is a multinomial choice model, which we estimate using the simulated method of moments technique of McFadden(1990). Our estimation of the demand side parameters recovers the coefficients of the risk aversion which are in line with the estimates found in other studies. We find that the risk aversion is inverse U-shaped with the youngest and oldest being more willing to take on risk. Our estimates are based on micro-moments evaluating the contribution of different consumer characteristics to the consumer's propensity to make a specific choice predicted consumer choices. We examine the goodness of fit of the model both to the moments used in estimation and with respect to aggregate statistics on market balance shares that were not used in the estimation and find that the model has a reasonably good fit. Lastly, we estimate the supply side of the model using standard panel data techniques. The translog cost function estimates point to the existence of an optimal scale both with respect to the number of consumers and total balance managed by the AFP fund. We do not find evidence of increasing returns to scale throughout, supporting the role for more than one firm in supplying the pension fund market.

After estimating the parameters of the demand and supply model, i.e. the distribution of consumers' tastes and companies' cost functions, we use the model to conduct counterfactual experiments that study firm and consumer behavior under alternative regulatory schemes. For example, instead of requiring AFP firms to deliver returns close to the industry average, an alternative regulation would explicitly regulate the choice of investment instruments. We evaluate the effectiveness of alternative designs of the pension system and compare them to the current regulatory environment using average life-time pension accumulation of individuals as a criterion for choosing among regulatory schemes. We find that the current Chilean 
regulatory rule creates incentives for AFPs to invest in riskier portfolios than they would otherwise choose were the riskiness of the portfolio explicitly regulated. It also leads to relatively lower levels of participation in the pension plan. Also, the choice of the portfolios under the current regulation is riskier than selection of portfolios the social planner would choose. Not surprisingly, it leads to a higher than desirable (by a social planner) volatility in accumulated balances.

The paper is organized as follows. Section two provides some background information on the Chilean private accounts system. Section three describes the consumer's choice problem and biefly outlines the oligopolistic model of firm price and location decisions. Section four describes the estimation strategy. Section five presents the empirical results and section six concludes.

\section{Industry Description and Related Literature}

\subsection{Industry Description}

As previously described, investors in the Chilean pension system are permitted to hold their money in only one AFP at a time. The rules governing switching between money managers changed several time over the years, but beginning in 1984 investors could switch funds without incurring any monetary costs. Pension funds charge fees for their services. Initially, the fee was a three part non-linear tariff consisting of a fixed fee, a variable fee proportional to the participant's contribution, and a fee proportional to participant's balance. Some companies also charged fees for withdrawal of funds, but in 1984 the government passed a regulation to disallow fees on the balance or on withdrawal. Currently, most AFPs charge a two-part tariff consisting of a fixed fee and a fee that is proportional to participant's contribution.

From the inception of the private accounts system, the government exerted

control over the investment choices. Initially, pension investments could only be 
held in government bonds, but over time the options expanded to include riskier assets, namely stocks and a higher degree of foreign investments. As an additional measure to reduce risk in the system, the government required that AFPs deliver a real return within 2 percentage points from the industry average, making the AFP firms responsible for covering low realizations of returns with their own capital. During the period after 1987, a number of AFPs had financial difficulties because of these restrictions and had to exit the market. $^{8}$

Up until 2000, each AFP firm essentially offered a single investment product. Starting in 2000, however, they were allowed to offer four instruments which differ according to the riskiness of the investment. ${ }^{9}$ In the analysis here, we use data from the time period prior to offering multiple investment instruments to simplify the modeling of the firm's choice of their product characteristics.

\subsection{Related literature}

There exists a substantial literature based on US data that studies to what extent performance of mutual fund managers, stock analysts etc. can be predicted from publicly available data on their characteristics and past performance. However, we are aware of only one study by Hortacsu and Syverson (2003) that focused on consumer choice among money managing companies; it explores consumer choices of S\&P 500 index funds, which exhibit return homogeneity and sizeable dispersion in fund fees. They find that consumer choices are largely driven by search costs, i.e. the cost of acquiring information about a fund which would be indicative of the fund's future performance. The authors conclude that this property combined with consumer heterogeneity in search costs and large proportion of consumers with high costs leads

\footnotetext{
${ }^{8}$ In each case, the exit was organized as a merger with one of the existing AFPs. The clients of an exiting AFP were transferred to its merging partner, though they could easily switch funds afterwards.

${ }^{9}$ Each of these instruments has a targeted age group. An investor's contributions are allocated by default into an age-appropriate fund unless he/she chooses otherwise.
} 
to a large dispersion in funds fees. The literature on consumer choice of services/ products in the presence of switching costs emphasizes entry barriers that arise as a result of switching costs, low incentives to invest in quality and adverse selection which arises if the switching cost is private information of the consumer. Some of the empirical and theoretical papers in this area include Beggs and Klemperer (1992), Calem, Gordy and Mester (2005), Gravelle and Masiero (2000), Kiser (2002), Klemperer (1987), Knittel (1997), Rhoades (2000), Stango (2002).

\section{Model}

This section describes the demand side model of consumer's choice of AFP fund and the supply side model of AFP funds pricing and location decisions in an oligopolistic environment. The supply side model is exposited in greater detail in a companion paper, Krasnokutskaya, Ressner and Todd (2008), which also proves existence of equilibrium.

\subsection{Demand side model of consumer's choice of AFP}

Under the Chilean private accounts system, consumers can freely switch AFP funds without incurring monetary switching costs. We, therefore, model the consumer's problem as a choice of fund in a given time period corresponding to a year.

A consumer $i$ in period $t$ is characterized by the tuple $\left(b_{i t}, y_{i t}, \gamma_{i t}, \epsilon_{i t}\right) \in B_{t}$ where $B_{t}$ is a convex subset of $\mathbb{R}^{3+J}, J$ is the total number of funds available, $b_{i t} \geq 0$ is the pension balance of consumer $i$ at time $t, y_{i t} \geq 0$ is the size of his pension contribution in period $t \gamma_{i t} \geq 0$ reflects consumer $i$ 's attitude towards risk, and $\epsilon_{i t}=\left\{\epsilon_{i j t}\right\}$ represent the unobservable part of consumer preferences for pension funds. The risk attitude parameter is assumed to depend on demographic characteristics, which is why we allow it to vary with $t$. In the following, we refer to a consumer 
characterized by $\left.\left(b_{i t}, y_{i t}, \gamma_{i t}, \epsilon_{i t}\right)\right) \in B_{t}$ as consumer $i$.

A consumer considers fund $j$ as being characterized by its return, $R_{j t}$, fees, and other non-pecuniary features related to the convenience of obtaining service from this fund. The consumer regards $R_{j t}$ as a random variable. We assume that consumer knows the portfolio compositions of all AFPs and, therefore, the joint and marginal distributions of AFP returns. Moreover, if the government requires the AFP to to guarantee annual return withing 2 percentage points of industry average, then consumers will incorporate this guaranteed return into their decision making. Specifically, a consumer recognizes that if he deposites his money with fund $j$, his actual return would be $\widetilde{R}_{j t}=\max \left(R_{j t}, \sum\left(R_{l t}\right) / J-0.02\right)$. Finally, we assume that consumer utility in a given time period is quadratic in retirement wealth and additive in other non-pecuniary costs. The fees associated with participating in various funds differ by consumers, because they depend on contribution levels.

The preferences of consumer $i$ from choosing fund $j$ in period $t$ are given by:

$$
U_{i j t}=w_{i j t} \widetilde{R_{j t}}-\gamma_{i t} s\left(w_{i j t}\right) w_{j i t}^{2}{\widetilde{R_{j t}}}^{2}+\xi_{j}+\epsilon_{i j t},
$$

where $w_{i j t}=\left(b_{i t}+y_{i t}-p_{i j t}\right)$ denotes the net retirement wealth (balance plus new contributions minus fees) of consumer $i$ given his choice of company $j$ at time $t$, and $s\left(w_{i j t}\right)=w_{i j t}^{-\alpha}$, with $\alpha>1 .{ }^{10}$. The variable $\xi_{j}$ represents the unobserved productspecific fixed effect. Thus, the expected utility of consumer $i$ is given by:

$$
E u_{i j t}=w_{i j t} \widetilde{\mu_{j t}}-\gamma_{i t} w_{i j t}^{2-\alpha}\left(\left(\widetilde{\mu_{j t}}\right)^{2}+\left(\widetilde{\sigma_{j t}}\right)^{2}\right)+\xi_{j}+\epsilon_{i j t}
$$

Consumers choose to invest their retirement savings at the company which offers the highest contemporaneous utility. Let $M_{j t} \subset B \subset \mathbb{R}^{3}$, where $M_{j t}\left(p_{j t}, \mathbf{p}_{-j t}, R_{j t}, \mathbf{R}_{-j t}\right) \equiv\left\{\left(b_{i t}, y_{i t}, \gamma_{i t}, \epsilon_{i j t}\right): E u_{i j t} \geq E u_{i k t}\right.$ for $\left.k \neq j \mid\left(p_{j t}, \mathbf{p}_{-j t}, x_{j t}, \mathbf{x}_{-j t}\right)\right\}$

\footnotetext{
${ }^{10}$ Pedersen and Satchell (2003) show that this modification of the quadratic utility function removes its implausible IARA and bliss point property
} 
denote the set of consumers that prefer AFP $j$ over its competitors $-j$. The demand for $\mathrm{AFP} j$ is given by

$$
D_{j t}\left(p_{j t}, \mathbf{p}_{-j t}, R_{j t}, \mathbf{R}_{-j t}\right)=\int_{M_{j t}\left(p_{j t}, \mathbf{p}_{-j t}, x_{j t}, \mathbf{x}_{-j t}\right)} d G\left(b_{t}, y_{t}, \gamma_{t}, \epsilon_{t}\right)
$$

where $G(\cdot)$ denotes the joint cdf of consumer's risk attitude, balance, contribution, and unobservable tastes. We assume that the joint distribution of consumer characteristics satisfies the following condition:

Condition 1: [Caplin and Nalebuff (1991)]: In a given period the joint probability density of consumers' unobserved preferences, risk attitude, balance, and

contribution , $g(b, y, \gamma, \epsilon)$ is such that $g(b, y, \gamma, \epsilon)^{-\frac{1}{4+J}}$, is a concave function over its support $B$, which is a convex subset of $\mathbb{R}^{3+J}$ with positive volume. In addition $R W^{\prime}=\sup _{\{b, y, \gamma, \epsilon\} \in B} R W$ is finite.

This condition is require for existence of equilibrium, as shown $\mathrm{n}$ Krasnokutskaya, Ressner and Todd (2008).

\subsection{The Decision to Participate in the Pension System}

Low participation rates is a key concern raised by critics of the Chilean pension system. As in many other Latin American countries, Chile has an informal sector of the economy comprised of workers without a wage contract, i.e. those who are self-employed or are paid on per-hour basis. The contributions to pension system are mandatory for formal sector workers but are voluntary for the part-time workers and the informal sector workers. Only a very small fraction of people for whom contributions are voluntary choose to contribute to pension system. However, some of these workers will still be participating in the pension system, because of previously held formal sector jobs for which they have some pension accumulations. Because the fraction of people participating is an important factor determining firm's profits as well as the level of government obligations, we modify our model to take into account 
the choice of whether to participate.

We assume that participation/contribution decisions are made an annual basis. Each year an individual decides whether to work in the formal or informal sector and to which fund he/she should allocate the current pension balance. Consider an individual characterized by $\left(b_{i t}, Y_{i 0 t}, Y_{i 1 t}, \gamma_{i t}, \tau_{i t}, \epsilon_{i t}\right)$ where $\tau_{i t}$ is individual $i^{\prime}$ s rate of substitution between consumption today and consumption at the time of retirement; $Y_{i 0 t}$ and $Y_{i 1 t}$ indicate yearly incomes that an individual can earn in the informal and formal sector. The set of possible choices includes $\{(j, 0),(j, 1)\}$ for every $j=1, . ., J$ where $(j, 0)$ corresponds to working in the informal sector and $(j, 1)$ corresponds to working in the formal sector. The utility individual derives form a choice $(j, k)$ is

$$
\begin{aligned}
U_{i(j, 0) t} & =w_{i(j, 0) t} \widetilde{R_{j t}}-\gamma_{i t} s\left(w_{i(j, 0) t}\right) w_{i(j, 0) t}^{2}{\widetilde{R_{j t}}}^{2}+\tau_{i t}\left(Y_{i 0 t}-0.9 Y_{i 1 t}\right)+\xi_{j}+\epsilon_{i(j, 0) t} \\
U_{i(j, 1) t} & =w_{i(j, 1) t} \widetilde{R_{j t}}-\gamma_{i t} s\left(w_{i(j, 1) t}\right) w_{i(j, 1) t}^{2}{\widetilde{R_{j t}}}^{2}+\xi_{j}+\epsilon_{i(j, 1) t}
\end{aligned}
$$

where $w_{i(j, k) t}=\left(b_{i t}+0.1 Y_{i 1 t}-p_{i(j, k) t}\right)$. If an individual never contributed before and does not contribute in period $t$, his/her utility is

$$
U_{i(0,0) t}=\alpha_{0}+\tau_{i t}\left(Y_{i 0 t}-0.9 Y_{i 1 t}\right)+\epsilon_{i(0,0) t}
$$

The rest of the demand analysis proceeds as before, with consumers who choose to participate in the system making a choice of pension fund. Consumer fund choice decisions define the set of clients served by each AFP as well the total amount of funds managed by a particular AFP in a year $t$.

\subsection{Supply side}

The supply side of the market is based on a modeling framework developed in a companion paper, Krasnokutskaya, Ressner and Todd (2008). The supply side market is made up of $J$ pension funds (we do not model the firm entry decision). The 
demand model assumed that consumers have quadratic utility with respect to retirement wealth. In this context, application of the mutual fund separation theorem would imply that money managers - the AFPs - will choose a convex combination of the risk-free asset and the market portfolio. The fund's portfolio can therefore be summarized by the share that the fund invests in the market portfolio (or equivalently by the correlation between the market excess return and funds excess return). We refer to this share as fund's choice of "location" and denote it by $x_{j t}$.

In the Chilean pension market, the regulatory agency does not allow AFPs to charge fees on balances or on withdrawal of funds. Therefore, we restrict our attention to the two part-tariff fee structure of the type:

$$
p_{i j t}=p_{j 0 t}+p_{j 1 t} y_{i t}
$$

where $p_{j 0 t}$ denotes company $j$ 's fixed fee and $p_{j 1 t}$ is company $j$ 's percentage fee on consumer $i$ 's pension contribution in period $t, y_{i t}$.

To describe the decision problem of the AFP firm, we first formulate a model for the production process that the AFP uses to provide its services. We think of the final of output of an AFP as being two-dimensional. It consists of the number of customers that receive services as well as the total balance that the AFP manages for them. We assume that all AFP's have access to the same technology, which may have economies of scale related to both inputs as well as the relative level of inputs. Additionally, we assume that AFPs may have firm-specific cost factors which reflect managerial talent or any other firm-specific productivity factor. Denote by $T B_{j t}$ the total balance under the management of $\operatorname{AFP} j$ during the time period $t$,

$$
T B_{j t}=\int_{M_{j t}\left(p_{j t}, \mathbf{p}_{-j t}, x_{j t}, \mathbf{x}_{-j t}\right)}\left(b_{i t}+y_{i t}-p_{i j t}\right) d G\left(, b_{t}, y_{t}, \gamma_{t}, \epsilon_{t}\right) ;
$$

and by $T Y_{j t}$ the total contributions made to $\mathrm{AFP} j$ during time period $t$,

$$
T Y_{j t}=\int_{M_{j t}\left(p_{j t}, \mathbf{p}_{-j t}, x_{j t}, \mathbf{x}_{-j t}\right)} y_{i t} d G\left(, b_{t}, y_{t}, \gamma_{t}, \epsilon_{t}\right) ;
$$


The cost function of the fund $j$ is given by a translog function $C\left(D_{j t}, T B_{j t}\right)$ such that

$$
\begin{aligned}
\ln \left(C\left(D_{j t}, T B_{j t}\right)\right)= & \gamma_{1} \ln \left(D_{j t}\right)+\gamma_{2} \ln \left(T B_{j t}\right)+\gamma_{3}\left(\ln \left(D_{j t}\right)\right)^{2}+ \\
& +\gamma_{4}\left(\ln \left(T B_{j t}\right)\right)^{2}+\gamma_{5} \ln \left(D_{j t}\right) \ln \left(T B_{j t}\right)+\nu_{j}
\end{aligned}
$$

where $\nu_{j}$ are firm fixed effects. Additionally, Chile's regulation concerning a minimum rate of return that the funds have to provide imposes an additional cost on the AFP which, in expectation, is equal to

$$
C_{j t}^{r e g}=E\left[\left(R_{j t}-R_{t}+0.02\right) \mid R_{j t}<R_{t}-0.002\right] T B_{j t}
$$

where $R_{t}$ denotes average return across all AFPs. ${ }^{11}$

The expected profit of AFP $j$ that chooses the location $x_{j t}$ and charges $p_{j t}=$ $\left(p_{0 j t}, p_{1 j t}\right)$ is given by

$$
E\left[\Pi_{j t}\left(p_{j t}, \mathbf{p}_{-j t}, x_{j t}, \mathbf{x}_{-j t}\right)\right]=p_{0 j t} D_{j t}+p_{1 j t} T Y_{j t}-C\left(D_{j t}, T B_{j t}\right)-C_{j t}^{r e g}
$$

in the unregulated system if its competitors locate at $\mathbf{x}_{-j t}$ and charge $\mathbf{p}_{-j t}$. The last term is only present under the regulation.

\subsubsection{Equilibrium conditions of the location-then-price game}

At a given point in time, competition between AFPs takes the form of a two-stage game. In the first stage, the AFP firms simultaneously and irrevocably choose their locations. In the second stage, each AFP observes the choices of the other firms and selects a price that is contingent on the chosen locations. Thereafter, the rate of return on the market portfolio is realized, interest is paid on consumers' net retirement wealth, and AFPs' profits accrue. We solve for the subgame perfect equilibrium by backward induction, as described in Krasnokutskaya, Ressner and Todd (2008).

\footnotetext{
${ }^{11}$ As previously noted, funds have to cover realizations of returns that are more than $2 \%$ below the industry average with their own capital.
} 


\section{Estimation Methodology}

This section first describes how we estimate the parameters of consumer preferences and of the industry cost structure from the data. Then it describes how we characterize and estimate firms' location decisions. In particular, we assume that the fund's location is summarized by its CAPM beta, which we estimate using historical data on returns.

\subsection{Consumer Preferences}

A consumer chooses one fund out of multiple discrete alternatives. As noted in the previous section, his/her preference for alternative funds is described by a random utility model, where utility depends on balances, current contribution level, fees, and the location of the firm. Consumers differ in their risk aversion in a way that depends on observable demographics as well as on unobservables (random coefficients). The demand model also allows includes alternative-specific fixed effects to accomodate unobserved differences in the perception of fund quality.

The demand model is estimated using McFadden's (1989) simulated method of moments (SMM) approach. The parameter vector $\theta$ is recovered as

$$
\theta=\operatorname{argmin}_{\theta}\left(d-P(\theta)^{\prime} W^{\prime} W(d-P(\theta))\right.
$$

Here $d$ denotes $J n \times 1$ vector of consumer choices with $d_{i j}=1$ if individual $i$ chose alternative $j$ and $P(\theta)$ represents the predicted choice given a vector of coefficients $\theta$. Therefore, $d-P(\theta)$ is a vector of residuals stacked by individual and by alternatives for a given individual. The matrix $W$ is $K \times J n$ array of instruments of rank $K \geq k$ where $k$ is the length of parameter vector.

The choice probability is estimated using a frequency simulator. McFadden(1989) shows that with a suitable choice of a simulator and matrix of instruments proportional to $\partial \ln \left(P\left(\theta^{*}\right) / \partial \theta\right.$, the method is asymptotically efficient. We implement 
the method using an iterative process. First, we find an 'initial consistent' estimator of $\theta^{*}$ using a matrix of non-optimal instruments $\left(X_{k i j}, X_{k i j}^{2}\right)$. Then we use the firststage estimator to construct nearly optimal instruments which are used to obtain final estimate of $\theta^{*}$. As required by the method, we use two independent sets of random draws in estimation: the first set to construct the instruments and the second set to simulate choice probabilities.

Finally, we compute variance - covariance matrix of estimated coefficients according to

$$
\Sigma=\left(R^{\prime} R\right)^{-1} R^{\prime} G R\left(R^{\prime} R\right)^{-1}
$$

where

$$
R=\lim _{n \rightarrow \infty} n^{-1} W P_{\theta}\left(\theta^{*}\right)
$$

and

$$
G=\lim _{n \rightarrow \infty} n^{-1}\left(1+r^{-1}\right) \sum_{t=1}^{t=n} \sum_{j=1}^{j=J}\left(P\left(j \mid \theta^{*}, X\right) W_{j t} W_{j t}^{\prime}-W_{\cdot t} W_{\cdot t}^{\prime} .\right.
$$

Here $r$ is the number of draws used in the frequency simulator.

\subsection{The Cost Function}

The parameters of the cost function are estimated using annual data on various components of firms' operational costs. This estimation is informative on potential scale effects both with respect to the number of customers served and the total balance managed by a particular fund, while allowing for the interdependence of these two factors in determining costs. We also allow costs to depend on the riskiness of the product the fund offers. To this end, we estimate the cost function using a flexible 'translog' functional form, where costs depend on the number of customers $\left(N_{j t}\right)$, the total balance managed $\left(B_{j t}\right)$ and the fund's location $\left(x_{j t}\right)$. Specifically, we assume 
that

$$
\begin{aligned}
\ln \left(C\left(N_{j t}, B_{j t}, x_{j t}\right)\right)= & \gamma_{1} \ln \left(N_{j t}\right)+\gamma_{2} \ln \left(B_{j t}\right)+\gamma_{3}\left(\ln \left(N_{j t}\right)\right)^{2}+\gamma_{4}\left(\ln \left(B_{j t}\right)\right)^{2}+(16) \\
& +\gamma_{5} \ln \left(N_{j t}\right) \ln \left(B_{j t}\right)+\gamma_{6} \ln \left(N_{j t}\right) \ln \left(x_{j t}\right)+\gamma_{7} \ln \left(B_{j t}\right) \ln \left(x_{j t}\right)(117) \\
& +\nu_{j}+\gamma_{10} D_{1981}+\ldots+\gamma_{28} D_{1999}+\epsilon_{j t}
\end{aligned}
$$

where $\nu_{j}$ are firm fixed effects and $D_{y}$ are year effects. The parameters are estimated using standard panel data methods.

\subsection{Recovering Fund's Locations}

The pension funds' choice of location or riskiness of fund's portfolio is an important component of both the demand and supply side models. However, this variable is not directly observable in the data and therefore needs to be inferred from information on the fund's history of returns. In implementing the model, we use the fund's CAPM beta to represent its location choice. More specifically, we work with a model of time varying beta and GARCH errors to recover funds' betas for use in cost function estimation. We also use this model to approximate consumer's forecast of the funds' expected returns and return volatilities. Our approach is based on Bollerslev at al.'s (1989) CAPM model with time varying covariances. Denote by $Y_{j, t}$ an excess return

of fund $j$ at time $t$ and by $Y_{m, t}$ an excess market return at time $t$. We assume that vector $\left(Y_{j, t}, Y_{m, t}\right)$ changes over time according to

$$
\begin{aligned}
Y_{j, t} & =b_{j}+\delta h_{j m, t}+\epsilon_{j t} \\
Y_{m, t} & =b_{m}+\epsilon_{m t}
\end{aligned}
$$

Additionally, $\epsilon_{t}=\left(\epsilon_{j t}, \epsilon_{m t}\right)$ is distributed according to $N\left(0, H_{t}\right)$ with

$$
\begin{aligned}
h_{j j, t} & =\gamma_{j j}+\alpha_{j j} \epsilon_{j, t-1}^{2}+\beta_{j j} h_{j j, t-1} \\
h_{m m, t} & =\gamma_{m m}+\alpha_{m m} \epsilon_{m, t-1}^{2}+\beta_{m m} h_{m m, t-1} \\
h_{j m, t} & =\gamma_{j m}+\alpha_{j m} \epsilon_{j, t-1} \epsilon_{m, t-1}+\beta_{j m} h_{j m, t-1}
\end{aligned}
$$


Model parameters are estimated via maximum likelihood. The beta values and forecasts are obtained using rolling 18 months window.

\section{Empirical Results}

\subsection{Descriptive statistics}

Table 1 presents some descriptive statistics derived from the administrative pension data, which includes men and women. The pension plan participant sample is fairly young, with a median age of 34 and an interquartile range of $27-42$. The median years of contribution is 3.83 years with an interquartile range of 1.41-7.58. The median balance is close to the median of one year's annual income.There is rising dispersion with age, particularly over the age 35-45 range. At subsequent ages, the dispersion remains roughly constant. There is also increasing dispersion in income up through age 40 , as exhibited by the interquartile range, after which it declines. The dispersion in income is not as large as the dispersion in balances, which might be expected given that balances represent a stock measure and income a flow measure.

Table 1: Descriptive Statistics

\begin{tabular}{|c|c|c|c|}
\hline & $25 \%$ centile & median & $75 \%$ centile \\
\hline age & 27 & 34 & 42 \\
\hline annual income (all) $\$$ & 20 & 1342 & 3196 \\
\hline annual income $($ age $=30) \$$ & 0 & 1250 & 2916 \\
\hline annual income $($ age $=40) \$$ & 10 & 1512 & 3705 \\
\hline annual income $($ age $=55) \$$ & 100 & 834 & 3235 \\
\hline balance (all) $\$$ & 283 & 1090 & 3381 \\
\hline balance $($ age $=30) \$$ & 190 & 930 & 2231 \\
\hline balance $($ age $=40) \$$ & 500 & 2500 & 6210 \\
\hline balance $($ age $=55) \$$ & 653 & 2670 & 7161 \\
\hline years contributing & 1.41 & 3.83 & 7.58 \\
\hline
\end{tabular}


We next turn to descriptive characteristics of the AFP firms. Table 2 shows the fixed and variable fees charged by the AFP firms in year 1999 and reveals substantial variation in the fees charged across firms. A number of funds do not charge any fixed fee. The AFP firm Habitat has the lowest variable fee at $2.84 \%$ of monthly contributions and no fixed fee. The firm Concordia has the highest fixed fee at $3.48 \%$ and also a relatively high fixed fee at 230 pesos per month.

\begin{tabular}{ccc}
\multicolumn{2}{c}{ Table 2: Fees Charged by } & AFP Firms \\
\hline \hline AFP & Percent Fee & Fixed Fee \\
\hline Concordia & 3.48 & 230 \\
Cuprum & 2.99 & 0 \\
Habitat & 2.84 & 0 \\
Planvital & 3.45 & 280 \\
Provida & 2.85 & 195 \\
Santa Maria & 3.15 & 100 \\
Summa & 3.15 & 230 \\
Magister & 3.4 & 220 \\
Union & 3.7 & 290 \\
Proteccion & 2.94 & 0 \\
Futuro & 3.25 & 0 \\
Formenta & 3.25 & 0 \\
\hline
\end{tabular}

In Table 3, we compare the market shares of the different funds in terms of the share of clients and the share of the total market balance under each firm's management. The table also shows the estimated CAPM-beta, with lower betas indicating lower risk. The fund with the largest market share both in terms of customers and balances is Provida, which manages pensions for about one-third of all pension plan participants. Provida is also one of the least risky funds. The AFP firm Santa Maria has the second largest market share in terms of clients but ranks lower in terms of balance shares. Its portfolio allocation is in the median risk range. The firm with the lowest fees, Habitat, is relatively low ranking in terms of numbers of share of customers but is in the top three in terms of share of total balances. There are also a number of funds in the market with very low shares of customers and of balances. For example, Fomenta has the riskiest portfolio, measured in terms of the beta, and 
also attracts few clients. In summary, there is substantial heterogeneity across firms in fee structures, in shares of clients and in shares of balances.

Table 3: Market Structure

\begin{tabular}{|c|c|c|c|}
\hline & N_ _Share & B_Share & Beta \\
\hline Concordia & 0.191 & 0.223 & 35.6 \\
\hline Cuprum & 0.018 & 0.005 & 54.0 \\
\hline Habitat & 0.058 & 0.133 & 40.0 \\
\hline Planvital & 0.027 & 0.011 & 52.5 \\
\hline Provida & 0.345 & 0.450 & 37.6 \\
\hline Santa Maria & 0.207 & 0.074 & 33.0 \\
\hline Summa & 0.076 & 0.053 & 50.0 \\
\hline Magister & 0.014 & 0.008 & 53.0 \\
\hline Union & 0.051 & 0.024 & 52.0 \\
\hline Proteccion & 0.013 & 0.013 & 55.0 \\
\hline Futuro & 0.000 & 0.001 & 38.0 \\
\hline Fomenta & 0.001 & 0.005 & 64.0 \\
\hline
\end{tabular}

\subsection{Model Estimates}

Tables 4, 5 and 6 present estimated model parameters and evidence on goodness of fit. As described above, we allow risk aversion (the $\gamma$ parameter) to depend on demographics and also allow for a random coefficient component to risk aversion to reflect unobservable sources of heterogeneity in people's attitudes towards risk. Theoretical models of dynamic savings accumulation decisions would suggest that age is an important characteristic in determining risk aversion, although its net effect on risk aversion is ambiguous. Older individuals are typically less willing to take on investment risk, because of a shorter time horizon until retirement, but may also be more willing to take on risk, because they have higher balances. 


\section{Table 4: Demand Estimation: Risk Aversion}

\begin{tabular}{lccc}
\hline \hline & Parameter & & Std. Error \\
\cline { 2 - 2 } mean & & \\
age $\geq 35$ & & \\
$35 \leq$ age $\leq 50$ & -3.36 & & 1.23 \\
age $\geq 50$ & -7.34 & & 1.34 \\
sigma & -5.36 & & 1.51 \\
\hline \hline
\end{tabular}

Table 5 presents estimates of absolute and of relative risk aversion at different ages. The Arrow (1965)-Pratt (1964) measure of absolute risk aversion (as a function of consumption) is given by

$$
-\frac{u^{\prime \prime}(c)}{u^{\prime}(c)}
$$

and the measure of relative risk aversion by

$$
-\frac{c u^{\prime \prime}(c)}{u^{\prime}(c)} \text {. }
$$

These are standard measures of risk aversion that stay constant up to affine transformations of the utility function. ${ }^{12}$ As seen in the table, people are estimated to be more risk averse at age 40 than at age 30 or 50 .

Table 5: Implied Risk Aversion

\begin{tabular}{cccc}
\hline \hline \multirow{2}{*}{ Age } & $\begin{array}{c}\text { Absolute Risk } \\
\text { Aversion }\end{array}$ & & $\begin{array}{c}\text { Relative Risk } \\
\text { Aversion }\end{array}$ \\
\cline { 2 - 2 } 30 & & & -2.24 \\
40 & -0.030 & & -2.98 \\
50 & -0.048 & & -2.11 \\
\hline \hline
\end{tabular}

In Table 6, we examine the importance of unobservables to the fit of the model. Specifically, we evaluate the fit of the moments under the original model and under

\footnotetext{
${ }^{12}$ The advantage of the relative measure vis-a-vis the absolute measure is that it accomodates the situation varying degrees of risk aversion at different levels of $c$ (for example, switching from being risk averse to risk loving and then back to risk averse).
} 
two restricted version of the model, one that sets the alternative-specific fixed effects to zero (i.e. shuts down permanent unobservable firm heterogeneity) and one that, in addition, suppresses the utility shock. We find that the fit of the moments is not greatly compromized by shutting down unobservable sources of heterogeneity, although the fit is certainly improved by including these components.

Table 6: Role of Unobservables

\begin{tabular}{cc}
\hline \hline & Proportion explained \\
\hline Observable part of utility function & $75 \%$ \\
Observable part plus fixed effects & $80 \%$ \\
Observable part plus fixed effects plus Weibull errors & $97 \%$ \\
\hline
\end{tabular}

Table 7 compares the model's aggregate predicted shares of annual contributions to pension funds to the empirical shares. Recall that in estimation we only used moments pertaining to shares of customers and share of balances. The moments related to shares of contributions were not used in estimating the model parameters, so this comparison could be viewed as a form of model validation. Generally, the model is able to identify the top five AFP firms in terms of shares of contributions and is fairly accurate in terms of predicting the actual contribution share for four of the five funds. The AFP firm Provida had the largest contribution share in the data, which is also predicted by the model. For the third (Concordia), though, the model overpredicts the contribution share. 


\section{Table 7: Aggregate Fit: Contribution Shares}

\begin{tabular}{|c|c|c|}
\hline & Actual & Predicted \\
\hline Concordia & $18.5 \%$ & $30.4 \%$ \\
\hline Cuprum & $1.3 \%$ & $0.8 \%$ \\
\hline Habitat & $12.1 \%$ & $8.4 \%$ \\
\hline Planvital & $2.0 \%$ & $1.3 \%$ \\
\hline Provida & $29.0 \%$ & $30.7 \%$ \\
\hline Santa Maria & $18.6 \%$ & $22.3 \%$ \\
\hline Summa & $9.3 \%$ & $8.5 \%$ \\
\hline Magister & $1.7 \%$ & $1.3 \%$ \\
\hline Union & $4.4 \%$ & $2.8 \%$ \\
\hline Proteccion & $2.5 \%$ & $1.0 \%$ \\
\hline Futuro & $0.1 \%$ & $0.01 \%$ \\
\hline
\end{tabular}

Table 8 provides AFP cost function estimates that are derived from panel data on firms, costs and cost components. We assume that the cost depends on the number of clients served, the total balance under management, and the firm's location choice. We specify the cost function flexibly as a function of linear and interaction effects in these variables. According to the estimates, once the pension fund reaches a certain size there are decreasing returns to scale. This implies that the market is efficiently served by more than one pension fund firm.

Table 8: TransLog Cost Function

\begin{tabular}{lccc}
\hline \hline & Parameter & & Std. Error \\
Constant & & \\
$\log ($ affiliates $)$ & -4.5 & & 0.95 \\
$\log ($ assets $)$ & 0.98 & & 0.28 \\
$(\log (\text { affiliates }))^{2}$ & 0.45 & & 0.14 \\
$(\log (\text { assets }))^{2}$ & 0.015 & & 0.021 \\
$\log ($ affiliates $) * \log ($ assets $)$ & -0.086 & & 0.012 \\
\hline \hline
\end{tabular}




\section{Policy Experiments}

When the Chilean pension system was designed, the government sought to limit downside market risk by placing restrictions on AFP investment behavior. As previously noted, current regulations require that AFPs guarantee a market return that is within $2 \%$ of the industry average. We next use our estimated demand and supply-side model to evaluate the effects of this regulatory restriction on AFP location choices, on individual pension performance and balance accumulations, and on participation rates in the pension fund program. For reasons of computational difficulty, our simulations are based on a market with three firms only (the largest firms in the market). In future work, we plan to extend the analysis to include more firms.

Our simulation compares the AFP location decisions and individual pension fund investment decisions under the current regulatory environment to those that would be realized (i) under a social planner and (ii) under an alternative form of regulation that would place an upper limit on the riskiness of the firm's portfolio (the CAPM beta).

Table 9 shows the average location decisions of firms under the three different scenarios (the social planner, the restriction on riskiness of the portfolio and the restriction on returns (the current regulation)). Interestingly, the current regulation that requires that returns not fall too far below the industry average leads to substantially riskier firm location decisions.

Table 9: Policy Experiments: Locations

\begin{tabular}{lccc}
\hline \hline & Mean & & Std. Dev. \\
Social Planner & 0.36 & & 0.12 \\
Restriction on Portfolio & 0.33 & & 0.15 \\
Restriction on returns & 0.45 & & 0.05 \\
\hline \hline
\end{tabular}

Table 10 compares the expected coverage rates of the pension system under the 
three different cases. As previously noted, a major concern of the Chilean government today is low coverage rates, with a substantial fraction of workers opting to work outside the formal sector of the economy and therefore to not participate in the pension program. The estimates in Table 10 show that the coverage under the current regulation is about $60 \%$, which is significantly lower than it would be under a social planner or under the alternative regulation that restricts portfolio risk directly. The lower coverage arises because some individuals opt not to participate in the higher risk environment.

\section{Table 10: Policy Experiment: Consumers}

\begin{tabular}{lccccc}
\hline \hline & Coverage & & $\begin{array}{c}\text { Mean } \\
\text { (Balance) }\end{array}$ & & $\begin{array}{c}\text { Std. Dev. } \\
\text { (Balance) }\end{array}$ \\
\cline { 2 - 2 } \cline { 5 - 6 } & & & & \\
Social Planner & $72 \%$ & & $35 \mathrm{mil}$ & & $13 \mathrm{mil}$ \\
Restriction on Portfolio & $75 \%$ & & $30 \mathrm{mil}$ & & $10 \mathrm{mil}$ \\
Restriction on returns & $60 \%$ & & $39 \mathrm{mil}$ & & $21 \mathrm{mil}$ \\
\hline \hline
\end{tabular}

\section{Conclusions}

Chile has one of the oldest individual-account pension systems and therefore provides a unique opportunity to study firm and consumer behavior under a well established private accounts system. The design of the Chilean pension system includes insurance features, in the form of a minimum return guarantee and a minimum pension guarantee, that are intended to protect investors against low levels of pension accumulations. These guarantees create the potential for moral hazard in consumers' investment decisions.

In this paper, we developed a demand and supply model of the Chilean pension fund market. In the demand model, a consumer chooses an AFP to manage his/her investments, taking into account pension fund fees and historical pension fund performance. Consumers are heterogeneous in terms of their demographics and 
in risk aversion. The supply side is modeled as an oligopolistic environment in which AFPs sequentially choose product location (mean and variance of the return), and the fixed and variable fees they charge for service while taking into account consumers' preferences for risk.

After estimating the parametes of the model, we use the model to assess the impact of government regulations on pension funds' choices of locations. We also study implications of regulations for the consumers' accumulated balances and for volatility in balances. We find that Chilean regulatory rule that mandates firms to guarantee returns within $2 \%$ of the industry average creates incentives for the AFP firms to invest in the riskier portfolios than they would choose under an alternative regulation that instead restricts the riskiness of their portfolio limited. Surely, this is an unanticipated effect of the regulation. Because the portfolio location choices that firms make are riskier, fewer people participate in the pension program, which is a particularly worrisome finding considering that the government places a high priority on increasing coverage rates. Also, the choice of the portfolios under the current regulation is riskier than would be the selection of portfolios that a social planner would choose. Not surprisingly, it leads to a higher than desirable (by social planner) volatility in accumulated balances. We find that from the point of view of social welfare, an alternative regulation that restricted directly the investment instruments of the pension fund rather than requiring them to achieve a performance near the mean would be more effective. 


\section{References}

[1] Alberto Arenas de Mesa, David Bravo, Jere R. Behrman, Olivia S. Mitchell, and Petra E. Todd (2006): "The Chilean Pension Reform Turns 25: Lessons from the Social Protection Survey," working paper, University of Pennsylvania.

[2] Anderson S., Goaree J., and R. Ramer (1997), "Location Location Location," Journal of Economic Theory, 77(1), pp. 102-127.

[3] Arrow, K. J. (1965) Aspects of the Theory of Risk-Bearing. Helsinki: Yrjö Hahnsson Foundation.

[4] Baeza, S. and F. Margozzini, and LL Arroyo (1995): "Quince años después: Una mirada al sistema privado de pensiones," Centro de Estudios Públicos

[5] Beggs Albert and Klemperer, Paul (1992): "Multi-Period Competition with Switching Costs," Econometrica, 60(3), p. 651-666.

[6] Berry S., Levinsohn J. and A. Pakes (1995), "Automobile Prices in Market Equilibrium," Econometrica, Vol 63 (4), pp.841-90.

[7] Berry S., Levinsohn J. and A. Pakes (2004), "Differentiated Products Demand Systems from a Combination of Micro and Macro Data: The New Vehicle Market," Journal of Political Economy, 112(1), pp. 68-104.

[8] Calem, Paul, Mathew Gordy and Larry Mester (2005): "Switching Costs and Adverse Selection in the Markets for Credit Cards: New Evidence," Federal Reserve Bank of Philadelphia, Working Papers.

[9] Caplin A. and B. Nalebuff (1991), "Aggregation and Imperfect Competition: On the Existence of Equilibrium," Econometrica, Vol.59 (1), pp. 25-59. 
[10] Caplin A. and B. Nalebuff(1986), "Multi-Dimensional product Differentiation and Price Competition," Oxford Economic Papers, New Series, Vol. 38, pp. 129145.

[11] Cheyre, Hernan. (1988): La previsión en Chile ayer y hoy. Santiago, Centro de Estudios Públicos.

[12] Cogan, John F. and Olivia S. Mitchell (2003): "Perspectives from the President's Commission on Social Security Reform." Journal of Economic Perspectives. 17(2). Spring.

[13] Gravelle, H. and Masiero G. (2000). "Quality incentives in a regulated market with imperfect information and switching costs: Capitation in general practice," Journal of Health Economics, 19(6), p. 1067-1088.

[14] Holzmann, Robert and Richard Hinz together with Hermann von Gersdorff, Indermit Gill, Gregorio Impavido, Alberto R. Musalem, Michal Rutkowski, Robert Palacios, Yvonne Sin, Kalanidhi Subbarao, Anita Schwarz (2005): Old-Age Income Support in the 21st Century: The World Bank's Perspective on Pension Systems and Reform, manuscript, The World Bank.

[15] Hortacsu, Ali and Chad Syverson (2004): "Product Differentiation, Search Costs, and Competition in the Mutual Fund Industry: A Case Study of S\&P 500 Index Funds," Quarterly Journal of Economics, v.119, p.403-456.

[16] Iglesias, Augusto and Rodrigo Acuña (1991): Chile: Experiencia con un regimen de capitalización 1981-1991. Santiago: CEPAL/PNUD.

[17] Kiser, E. (2002): "Predicting Household Switching Behaviorand Switching Costs at Depository Institutions," Review of of Industrial Organization, 20(4), p. 349365 . 
[18] Klemperer, Paul (1998): "The Competitiveness of markets with Switching Costs," Rand Journal of Economics, 18(1), p. 137-150.

[19] Knittel, C. (1997): "Interstate Long-Distance Rates: Search Costs, Switching Costs, and Market Power," Review of Industrial Organization, 12(4), p. 519-536.

[20] Krasnokutskaya, Elena, Ressner, Ludwig and Petra Todd (2008): "Choice of Product under Government Regulation: The Case of Chile's Privatized Pension System," working paper.

[21] McFadden D.(1989), "A Method of Simulated Moments for Estimation of Discrete Response Models Without Numerical Integration," Econometrica, 57(5), pp. $995-1026$

[22] Mitchell, Olivia S., Gary R. Mottola, Stephen P. Utkus and Takeshi Yamaguchi (2006): "The Inattentive Participant: Portfolio Trading Behavior in 401(k) Plans," working paper.

[23] Mitchell, Olivia S. (1998): "Administrative Costs of Public and Private Pension Plans," in Privatizing Social Security, Ed. Martin Feldstein, NBER, Chicago: University of Chicago Press, 1998: 403-456.

[24] Mitchell, Olivia S. "Evaluating Administrative Costs in Mexico's AFORES Pension System," http://rider.wharton.upenn.edu/ prc/PRC/WP/wp99-1.pdf

[25] Pakes A., Porter J., Ho K. and J. Ishii (2006), "Moment Inequalities and Their Application," Working Paper.

[26] Pedersen C. and A. Satchell (2003), "Utility Functions whose Parameters Depend on Initial Wealth," Bulletin of Economic Research, 55(4), pp. 377-371.

[27] Pratt, J. W. (1964), "Risk Aversion in the Small and in the Large", Econometrica, Vol. 32, p.122-36. 
[28] Rhoades, S. (2000): "Retail Commercial Banking: An Update on a Period of Extraordinary Change," Review of Industrial Organization, 16(4), p. 357-366.

[29] Stango, V. (2002): "Pricing with Consumer Switching Costs: Evidence from the Credit Card Market, " Journal of Industrial Economics, 50(4), p. 475-492 